\title{
Using Business Plans For Teaching Entrepreneurship
}

\author{
John Zimmerman, Ed.D., Zayed University, UAE
}

\begin{abstract}
Many educators use the preparation of a Business Plan as a culminating assignment in entrepreneurship courses. Additionally, a number of institutions and organizations conduct business plan competitions to further entrepreneurship education. The objective for both of these exercises is to prepare student entrepreneurs for the challenging task of authoring a coherent and compelling document to communicate their proposed new venture to a variety of audiences including potential investors, lenders, employees, and partners. Some research shows that business plans are not always the key success factor for the success of new ventures, but the exercise of writing a business plan is an important planning tool for entrepreneurs and a valuable integrative educational process for students, because it requires the student to employ concepts from a variety of their courses including marketing, finance, accounting, strategy, operations, and human resources. This paper provides a case study of a recommended method for teaching students how to prepare business plans using the best known methods from the literature, and from the requirements of organizations that finance new ventures. The case study also provides suggested tools for writing the business plan, and a rubric for evaluating the plan.
\end{abstract}

Keywords: Business Plan; Entrepreneurship; Executive Summary; Market Analysis; Financial Projections

\section{INTRODUCTION}

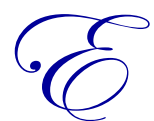

ntrepreneurship education is defined as "the conveyance of entrepreneurial knowledge to students in terms of concepts, skills, and behaviors (Gartner, 1990) that entrepreneurs possess and use" (Young, 1997). About $2 / 3$ of the universities and colleges in the United States (over 2,000) recognize the importance of entrepreneurship education by offering a course in entrepreneurship, with many offering multiple courses or sequences of courses leading to an undergraduate minor or graduate major (Cone, 2012). A significant activity in these courses is often the preparation of a business plan. Researchers define a business plan as a written document that describes an organization's present state and its plans to achieve some desired future state through an articulation of its vision, mission, strategy, tactics, and goals/objectives (Busentiz, 2005). The writing of a business plan has been shown to reduce the likelihood that a firm will be terminated before seeking funding, acquiring customers, or promoting the firm (Shane, 2004), thereby underscoring their importance. In fact, of the 100 top universities in US News and World Report's 2004 ranking, 78 had at least one course dealing with business plan education; and 10 of the top 12 conducted business plan competitions (Honig \& Karlsson, 2004). Studies examining entrepreneurship curricula show that a majority of classes and course content include the preparation and writing of business plans (Edelman, 2004; Vesper \& Gartner, 1999). The preparation of a business plan and/or entry into a business plan competition is used by many instructors as an effective way to teach the principles of entrepreneurship, and is considered to be one of the first steps in creating a new venture (Delmar, 2004). Most popular entrepreneurship textbooks articulate many different models for content and the process of crafting a compelling business plan. Since a business plan may be required for many different audiences - prospective lenders, investors, employees, key managers, vendors, etc. - perhaps a wide variety of business plan models should exist (White, Hertz, \& D'Souza, 2011).

Further anecdotal information concerning business plans exists. For example, launch a Google $\mathrm{TM}^{\mathrm{TM}}$ search for "writing + business plans" and approximately 202 million hits are obtained. The New York Times lists 43 business plan competitions in an admittedly incomplete list (2009). In fact, there are so many business plan competitions that 
a specialized and searchable website www.bizplancompetitions.com, claiming to be "the world's most complete listing of entrepreneurship and business plan competitions", lists over 200 such contests for the current year (2012).

Given the acceptance of business plans as a methodology for teaching entrepreneurship, this paper shall use a review of the literature to first provide a discussion of general approaches to entrepreneurship education, arguing for the utilization of business plans as an experiential or situational learning tool. Finally, a recommended methodology for using business plans as an integrative culminating learning assignment shall be presented.

\section{TEACHING ENTREPRENEURSHIP}

While most educators use business plans to teach entrepreneurship, not all researchers agree that they are significant for the success of new ventures. One argument involves the fact that since business plans are best written by the founders themselves, at the most critical point it the venture's history, its creation, the time required is not worth the benefit (Bhide, 2000). Other studies conducted to measure the relationship between the preparation of a business plan and the firm's success show little connection between the two (Lange, Bygrave, Mollov, Pearlmutter, \& Singh, 2007). Significant research using the Panel Study for Entrepreneurship Research Database (PSED) refutes these contentions by stating (Liao \& Gartner, 2009):

We believe that challenging prospective entrepreneurs to accomplish a formal business plan early in the venture creation process will likely enable them to engage in additional start-up behaviors that could further the process of business creation. By engaging in venture creation activities earlier rather than later, prospective investors and other venture supporters might ascertain earlier whether a fledgling idea has potential as an ongoing business.

The importance of a written plan document is very important for potential investors, particularly for venture capitalists. The initial screening and due diligence by investors has been shown to be based upon the business plan document (Zacharakis \& Meyer, 2000). Additionally, the three primary criteria used by investors to make investment decisions: 1 ) entrepreneurial/team capabilities; 2) product/service and market characteristics, and 3) financial needs of the firm, all of which can be best communicated using a business plan (Fried \& Hisrich, 1994). Using a business plan exercise seems critical for entrepreneurial success and therefore for entrepreneurial education.

Business plan preparation is also important for entrepreneurship education. Research shows that entrepreneurship education is enhanced through the use of application-based methodology as opposed to theorybased approaches (Harrison \& Leitch, 2005). This is due to the experiential nature of entrepreneurship. Many scholars believe the best way to teach the entrepreneurial context is through providing students with learning experiences (White, Hertz, \& D'Souza, 2011). Teaching entrepreneurship is seen as similar to teaching a craft such as medicine or architecture, where the student must acquire procedural as well as declarative knowledge (Anderson, 1983). Declarative knowledge is information of which students are consciously aware, that can be acquired from textbooks, and that students can clearly report, such as on examinations. Procedural knowledge is expertise and know-how acquired through practice, and is more difficult for students to articulate (Ambrosini \& Bowman, 2001). Procedural knowledge is best acquired through experiential learning such as internships, residencies, etc. In the case of teaching entrepreneurship it is often difficult to provide these types of opportunities, so alternative methods must be devised. Involving students in a analyzing a problem situation that requires identification and analysis of alternative solutions, such as preparing a business plan, is a valuable method for experiential learning because it requires the integration of previously acquired procedural knowledge (finance, marketing, strategy, etc.). This technique can provide students with the opportunity to connect theory from other subject matter with its practical application.

To be most effective, literature shows that experiential learning exercises must be as realistic as possible, or as Honig (2004) recommends "credible, relevant, and illustrative." Additionally, these exercises should be grounded in theory from supporting disciplines (finance, marketing, etc.), and in the prevailing entrepreneurship research. Therefore the use of a business plan assignment should be preceded with learning exercises connecting theory from other previous business courses to entrepreneurship. Also, lectures, cases, and reading assignments addressing the prevailing theory in the field of entrepreneurship should be conducted. A number of publishers have excellent textbooks that provide this material. Several of these textbooks are noted in the Reference Section. At a minimum, in 
a general entrepreneurship course it is suggested that the history of entrepreneurship; the entrepreneurial mind-set; the process of initiating new ventures; and growth, management and exit strategies be discussed. Additionally the various types of entrepreneurial activity such as social and corporate entrepreneurship, family owned businesses, and small/medium enterprise (SME) should be discussed in depth. After this learning has been accomplished and assessed, the business plan exercise can be introduced.

\section{BUSINESS PLAN CULMINATING ASSIGNMENT}

The exercise of preparing a business plan preparation assignment requires adequate preparation by the instructor. In planning the exercise the instructor first needs to address the most prevalent student questions: 1) are the plans to be individually prepared or will team plans be allowed, 2) how long and what format will the plans be (how many words), 3) how much time will be allowed for preparation, 4) what types of ideas are acceptable or not acceptable, and 5) how will the plan be assessed? If this is a required course and/or the students are actually considering starting their own business, it is suggested individual plans be used. Team plans could be allowable in elective courses but grading is then compromised. As a compromise the instructor could require individual plans for but volunteer to be an advisor for the best plans and allow team formation for business plan competition submissions. Required length is a more difficult question. Many business plan competitions require no more than 30 pages which is about 7,500 words. The inclusion of tables, charts, or graphics can impact page count significantly so require word count, something that is easily available from word processing software. That obviously means more pages. Require APA format. Allowable time for the plan preparation is about one-half of the time allotted for the course. Idea generation is often the most difficult issue for students so spend considerable time in class discussing this problem. Generally, do not exclude any types of ideas although discourage restaurants and other retail ideas unless they are truly novel, and encourage corporate and social entrepreneurship projects. Also encourage the students to discuss their ideas with their instructor before proceeding, and to generate an outline for instructor approval. As for assessment, provide a rubric with specific information as to how the plans are graded. This rubric has been developed over the years using information from various competitions and especially from the criteria used by investors to evaluate plans. By using a specific rubric students are provided with clear expectations for their plan. More about this rubric is provided later, and a copy of the rubric is provided with this paper.

\section{GENERATING IDEAS}

Opportunity recognition can be defined as the discovering of a clear idea for a business or developing an idea into a more feasible business concept over time (De Koning \& Muzyka, 1999). While some students will come to class with a clear idea as to what their business idea will be, many students find this to be the most difficult part of the assignment. Innovation and creativity are difficult, especially when under the pressure of satisfying the requirements of a course. To assist in the process a discussion of opportunity creation or recognition is in order. Opportunity creation requires innovation and invention (Hisrich, Peters, \& Sheperd, 2008). The first type of innovation is breakthrough (penicillin, the internet, nanotechnology). This often requires pure scientific discovery. Technological innovation involves using breakthrough innovation to achieve advancements in products or markets. Examples might include using touch screen technology to produce tablet computers or using wireless technology for instant messaging. Finally, ordinary innovations do not involve technology push but rather a market push. Novel consumer products such as Crocs, a new type of sandal, or using Velcro for new clothing items are good examples. Demographics are often important for ordinary innovation. Others recognize opportunities and design their venture to capitalize on demographic trends (aging of the population), unexpected events (9/11 terrorist attacks), technology developments (iPhone ${ }^{\mathrm{TM}}$ applications), new government regulations (the Dodd/Frank Act), incongruities between consumer expectations and reality (FedEx), process needs (health foods), industry changes (home healthcare), perceptual changes (travel industry), and knowledge-based concepts (internet telephony, robotics) (Kurato, 2009). The acquisition of existing businesses, implementing an idea for a business from one part of the world to another, or franchising are all considered as legitimate ideas for the purposes of this course. Additionally, social and corporate entrepreneurship ideas should be encouraged.

A useful exercise is to list these general categories: technological, breakthrough, and ordinary innovation, extension of existing ideas, franchising, corporate entrepreneurship, and social entrepreneurship have the three person teams think of examples and ideas for each and report to the class. Another is to have the students select an 
area in which they have personal interest and think of businesses that could be created around these areas. The classroom is definitely a challenging environment for creativity. Students are often reluctant to engage for various reasons including fear of criticism. Setting the tone for discussion is very important, as is using small group discussions with report out to the class is sometimes useful. This part of the course needs to be fun so that the students are open to creative and innovative thinking.

Students should come up with one or two ideas before the notion of evaluating the potential for each idea is introduced. If the course is a general entrepreneurship course the process of preparing the business plan is more important than the idea itself. For learning entrepreneurship it is better to have a good plan for a bad idea than a bad plan for a good idea.

\section{WRITING THE PLAN}

The most important point for students to understand is that writing a business plan is an integrative exercise. All elements of a business education from accounting to organizational development are necessary to employ in creating a coherent plan. Students should be able to draw upon and demonstrate knowledge in their other courses such as accounting, finance, marketing, organizational behavior, human resources, operations, strategy, etc. As an educational exercise there is no better tool for teaching entrepreneurship, and for allowing students to see the interrelationships between and importance of their other courses. To assist in the process a template has been developed based upon information from the United States Small Business Association (Small Business Association). The template has been provided in Appendix A. This is available in word processing template format. The students can use the template as a tool to guide their writing and as a format for preparation. Basic instructions are provided for each section that can be deleted and replaced with content. Additionally, a sample of an excellent plan from a previous course is provided to the students demonstrate what is expected. William Sahlman has provided an excellent and very readable article addressing key dimensions for business plans that should be provided for students (Sahlman, 1997).

\section{EVALUATING THE PLAN - RUBRICS}

A great deal of literature exists regarding what constitutes a good business plan. Kurato (2009) emphasizes the importance of setting realistic goals, anticipating problems with contingency planning, demonstrating commitment and dedication by the founders, the entrepreneurs having technical and business experience, and focusing on identifying a market niche or segment. Hisrich (2008) lists how investors (acceptable potential return and consistency with firm strategy) and lenders (ability to repay) evaluate a plan. Timmons (2009) provides rationale as to why the plan is important as a communication tool and a roadmap for future management of the organization. Included in Appendix B is a suggested Rubric designed for evaluating student business plans. This Rubric is based upon the literature, synthesis of business plan competition evaluation criteria, and information from how investors and lenders assess plans. For student plans, consistent assessment methodology and feedback are obviously very important. Students want to not only know their grade, they want to how that grade was determined, and that this grade was based upon consistent criteria as compared to their peers. Often investors and other business executives can be invited to help evaluate the plans so specific evaluation guidelines must be provided so that reliable assessment between reviewers is maintained.

\section{CONCLUSION}

The objectives for this paper are to provide a rationale, process, and tools for using business plans as an integrative teaching methodology for entrepreneurship. A discussion of the significance of business plan preparation for entrepreneurs and students is provided. Recommendations are provided for one of the most difficult area for students, discovering an idea. Additionally, a template is included as a guideline for the student plans. A comprehensive rubric is then provided to assist instructors in consistently evaluating the plans. It is hopeful this information will assist instructors in using a business plan preparation assignment as an integrative culminating assessment tool. 


\section{AUTHOR INFORMATION}

John Zimmerman, Ed.D. After a successful career in industry as a senior executive in financial and entrepreneurial positions with recognized industry leaders such as General Electric Company, Caterpillar Corporation, Intel Corporation; and with venture capital financed emerging companies such as Level One Communications and iSuppli Corporation, Dr. Zimmerman secured his doctorate from Pepperdine University in Malibu, California. He has taught at Pepperdine University Graziadio School of Business, the University of Southern Nevada (now Roseman University of Health Sciences), and Zayed University in Abu Dhabi, UAE. Currently he is an associate professor and the director for graduate programs at Zayed University. His research interests include entrepreneurship and entrepreneurial finance. E-mail: john.zimmerman@zu.ac.ae

\section{REFERENCES}

1. A guide to business plan competitions. (2009, November 11). Retrieved February 7, 2012, from New York Times: http://www.nytimes.com/interactive/2009/11/11/business/smallbusiness/Competitions

2. Ambrosini, V., \& Bowman, C. (2001). Tacit knowledge: Some suggestions for operationalization. Journal of Management Studies , 38(6), 811-829.

3. Anderson, J. (1983). Language, Memory, and Thought. Cambridge, MA: Harvard University Press.

4. Bhide, A. (2000). The Origin and Evolution of New Businesses. New York: Oxford University Press.

5. Busentiz, L., Fiet, J., \& Moesel, D. (2005). Signaling in venture capitalist new venture team funding decisions: does it indicate long-term venture outcomes? Entrepreneurship Theory \& Practice , 29(1) 1-12.

6. Business Plan Competitons. (2012, February 12). Retrieved February 12, 2012, from www.bizpplancompetitions.com

7. Bygrave, W., Lange, J., \& Evans, T. (2004). Do business plan competitions produce winning businesses? Frontiers of Entrepreneurship Research. Wellesley, MA: Babson College.

8. Castrogiovanni, G. (1996). Pre-startup planning and the survival of new small businesses: Theoretical linkages. Journal of Management 22 (6), 801-822.

9. $\quad$ Cone, J. (2012, April 2). Kauffmann Foundation. Retrieved April 2, 2012, from http://www.kauffman.org/entrepreneurship/teaching-entrepreneurship-in-colleges.aspx

10. Consumer Electronics Association. (n.d.). 2008 Outlook. Retrieved June 20, 2008, from www.ce.org

11. De Koning, R., \& Muzyka, D. (1999). Conceptualizing opportunity recognition as a socio-cognitive process. Stocholm, Sweden: Centre for Advanced Studies in Leadership.

12. Delmar, F., \& Shane, S. (2004). Legitimating first: organizing activities and the survival of new ventures. Journal of Business Venturing , 19(3), 385-410.

13. Edelman, L. (2004). Burn Your Business Plan: What Investors Really Want From Entrepreneurs. Academy of Management and Learning , 3(3), 331.

14. Fried, V., \& Hisrich, R. (1994). Toward a model of venture capital investment. Financial Management, 23(3), 28-37.

15. Gartner, W. (1990). What are we talking about when we talk about entrepreneurship? Journal of Business Venturing, 5(1), 15-28.

16. Harrison, R., \& Leitch, C. (2005). Entrepreneurial learning: researching the interface between learning and the entrepreneurial context. Entrepreneurial Theory and Practice , 29(4), 351-372.

17. Hisrich, R., Peters, M., \& Sheperd, D. (2008). Entrepreneurship. New York, NY: McGraw- Hill Companies.

18. Honig, B., \& Karlsson, T. (2004). Institutional forces and the written business plan. Journal of Management 30, 1, 29-48.

19. Ibbotson, R. G., \& Chen, P. (2003, Jan/Feb). Long run returns: Participating in the real economy. Financial Analysts Journal , 59 (1), pp. 88-98.

20. International Monetary Fund. (n.d.). Retrieved 30 2008, July, from www.imf.org

21. Kurato, D. (2009). Entrepreneurship: Theory, Process, Practice. Mason, OH: South-Western Cenage Learning.

22. Lange, J., Bygrave, W., Mollov, A., Pearlmutter, M., \& Singh, S. (2007, June 18). Do business plans make no difference in the real world? A study of 117 new ventures. Retrieved March 2, 2012, from Babson College: http://www/babson.edu/entrep/fer/2005FER/chapetr_xii3.html 
23. Liao, J., \& Gartner, W. (2009, February). Small Business Office of Advocacy. Retrieved March 10, 2012, from www.sba.gov/advo

24. Pathak, R. (2003 Public Administration: Challenges of Inequality and Exclusion). Creativity, Innovation and Entrepreneurship: the New Public Management Tools to Combat Inequality and Exclusion in the 21st Century. 64-76.

25. Sahlman, W. (1997, August). How to write great business plans. Harvard Business Review , pp. 99-108.

26. Shane, S., \& Delmar, F. (2004). Planning for the market: business planning before marketing and the continuation of organizing efforts. Journal of Business Ventures , 19(6), 767-785.

27. Small Business Association. (n.d.). Retrieved January 15, 2012, from http://web.sba.gov/busplantemplate/BizPlanStart.cfm

28. Timmons, J., \& Spinelli, J. S. (2009). New Venture Creation: Entrepreneurship for the 21 st Century. New York, NY: McGraw-Hill Companies.

29. Vesper, K., \& Gartner, W. (1999). University Entrepreneurship Programs. Retrieved March 15, 2012, from http://www.marshall.usc.edu/entrepreneur/postoffice/Compendium.pdf

30. White, R., Hertz, G., \& D'Souza, R. (2011). Teaching a craft - enhancing entrepreneurship pedgogy. Small Business Institute Journal , 7(2), 1-14.

31. Young, J. (1997). Entrepreneurship eductaion and learning for university students and practicing entrepreneurs. In D. S. (Eds.), Entrepreneurship 2000. Chicago, IL: Upstart Publishing.

32. Zacharakis, A., \& Meyer, G. (2000). The potential of actuarial decision models: Can they improve the venture capital investment decision? Journal of Business Venturing , 15(4), 324-346. 


\section{APPENDIX A}

\section{$\underline{\text { Business Plan for a Startup Business }}$}

The business plan consists of a narrative and several financial worksheets. The narrative template is the body of the business plan. It contains more than 150 questions divided into several sections. Work through the sections in any order that you like, except for the Executive Summary, which should be done last. Skip any questions that do not apply to your type of business. When you are finished writing your first draft, you'll have a collection of small essays on the various topics of the business plan. Then you'll want to edit them into a smooth-flowing narrative. Use graphics, images, and tables/charts to make your plan more understandable and readable.

The real value of creating a business plan is not in having the finished product in hand; rather, the value lies in the process of researching and thinking about your business in a systematic way. The act of planning helps you to think things through thoroughly, study and research if you are not sure of the facts, and look at your ideas critically. It takes time now, but avoids costly, perhaps disastrous, mistakes later.

This business plan is a generic model suitable for all types of businesses. However, you should modify it to suit your particular circumstances. Before you begin, review the section titled Refining the Plan, found at the end. It suggests emphasizing certain areas depending upon your type of business (manufacturing, retail, service, etc.). It also has tips for fine-tuning your plan to make an effective presentation to investors or bankers. If this is why you're creating your plan, pay particular attention to your writing style. You will be judged by the quality and appearance of your work as well as by your ideas.

It typically takes several weeks to complete a good plan. Most of that time is spent in research and re-thinking your ideas and assumptions. But then, that's the value of the process. So make time to do the job properly. And finally, be sure to keep detailed notes and provide references for your sources of information and on the assumptions underlying your financial data.

Specifically this assignment requires:

- Individual 7,000 (minimum) word paper. Prepare a business plan according to the guidelines provided in the class and from the article How to Write a Great Business Plan by William Sahlman.

- $\quad$ The plan shall follow the Template and Rubric. The student shall demonstrate an ability to apply and refer to the Sahlman text and class material to their plans. In the Financial Section please explain why your venture might appeal to corporate investors.

- $\quad$ The paper should be in typed in a minimum size of 12-font with one and half line spacing. Use section and sub-headings as applicable. You should have a title page and table of contents. Be sure to edit and spell check the paper before submission. The paper must be submitted in Word format. Late assignments without an approved official extension will have 2 points deducted for every day late. Assignments submitted more than 4 weeks past the due date will not be accepted.

\section{Executive Summary}

Write this section last. We suggest that you make it two pages or fewer. Include everything that you would cover in a five-minute interview.

Explain the fundamentals of the proposed business: What will your product be? Who will your customers be? Who are the owners? What do you think the future holds for your business and your industry?

Make it enthusiastic, professional, complete, and concise.

If applying for a financing, state clearly how much you want, precisely how you are going to use it, and how the money will make your business more profitable, and will help to ensure an acceptable return for investors. 


\section{General Company Description}

What business will you be in? What will you do?

Vision Statement: What is the Vision for your business? What do you hope your business to achieve? A Vision Statement is a broad long-term representation of the company and its stakeholders as projected in the future, such as a description of the company's reputation, including how consumers view its products and/or services.

Mission Statement: Many companies have a brief mission statement, usually in 30 words or fewer, explaining their reason for being and their guiding principles. If you want to draft a mission statement, this is a good place to put it in the plan.

Company Goals and Objectives: Goals are destinations-where you want your business to be. Objectives are progress markers along the way to goal achievement. For example, a goal might be to have a healthy, successful company that is a leader in customer service and that has a loyal customer following. Objectives might be annual sales targets and some specific measures of customer satisfaction.

To whom will you market your products? (State it briefly here-you will do a more thorough explanation in the Marketing Plan section).

Describe your industry. Is it a growth industry? What changes do you foresee in the industry, short term and long term? How will your company be poised to take advantage of them?

Describe your most important company strengths and core competencies. What factors will make the company succeed? What do you think your major competitive strengths will be? What background experience, skills, and strengths do you personally bring to this new venture?

Legal form of ownership: Sole proprietor, Partnership, Corporation, Limited liability corporation (LLC)? Why have you selected this form?

A timeline of listing key events and expected date of completion is important. To make the plan flexible list these key events in months or quarter from start date or financing date.

\section{Products and Services}

Describe in depth your products or services (technical specifications, drawings, photos, sales brochures, and other bulky items belong in Appendices).

What factors will give you competitive advantages or disadvantages? Examples include level of quality or unique or proprietary features.

What are the pricing, fee, or leasing structures of your products or services?

\section{Marketing Plan}

The 5 P's of Marketing. Be certain to begin by analyzing your product or service in terms of the 5 P's - Product, Price, Promotion, Place, and People (Customers).

Market research - Why?

No matter how good your product and your service, the venture cannot succeed without effective marketing. And this begins with careful, systematic research. It is very dangerous to assume that you already know about your intended market. You need to do market research to make sure you're on track. Use the business planning process as your opportunity to uncover data and to question your marketing efforts. Your time will be well spent.

Market research - How? 
There are two kinds of market research: primary and secondary.

Secondary research means using published information such as industry profiles, trade journals, newspapers, magazines, census data, and demographic profiles. This type of information is available in public libraries, industry associations, chambers of commerce, from vendors who sell to your industry, and from government agencies.

Start with your local library. Most librarians are pleased to guide you through their business data collection. You will be amazed at what is there. There are more online sources than you could possibly use. Your chamber of commerce has good information on the local area. Trade associations and trade publications often have excellent industry-specific data.

Primary research means gathering your own data. For example, you could do your own traffic count at a proposed location, use the yellow pages to identify competitors, and do surveys or focus-group interviews to learn about consumer preferences. Professional market research can be very costly, but there are many books that show small business owners how to do effective research themselves.

In your marketing plan, be as specific as possible; give statistics, numbers, and sources. The marketing plan will be the basis, later on, of the all-important sales projection.

Economic Facts about your industry:

- What is the total size of your market?

What percent share of the market will you have? (This is important only if you think you will be a major factor in the market.)

- $\quad$ Current demand in target market.

Trends in target market - growth trends, trends in consumer preferences, and trends in product development.

- $\quad$ Growth potential and opportunity for a business of your size.

What barriers to entry do you face in entering this market with your new company? Some typical barriers are:

High capital costs

High production costs

High marketing costs

Consumer acceptance and brand recognition

Training and skills

Unique technology and patents

Unions

Shipping costs

Tariff barriers and quotas

- And of course, how will you overcome the barriers?

- How could the following affect your company?

o $\quad$ Change in technology

o Change in government regulations

o Change in the economy

o Change in your industry 
Product/Services

In the Products and Services section, you described your products and services as you see them. Now describe them from your customers' point of view.

Features and Benefits

List all of your major products or services. For each product or service:

- $\quad$ Describe the most important features. What is special about it?

- Describe the benefits. That is, what will the product do for the customer?

Note the difference between features and benefits, and think about them. For example, a house that gives shelter and lasts a long time is made with certain materials and to a certain design; those are its features. Its benefits include pride of ownership, financial security, providing for the family, and inclusion in a neighborhood. You build features into your product so that you can sell the benefits.

What after-sale services will you give? Some examples are delivery, warranty, service contracts, support, follow-up, and refund policy.

Customers

Identify your targeted customers, their characteristics, and their geographic locations, otherwise known as their demographics.

The description will be completely different depending on whether you plan to sell to other businesses or directly to consumers. If you sell a consumer product, but sell it through a channel of distributors, wholesalers, and retailers, you must carefully analyze both the end consumer and the middleman businesses to which you sell.

You may have more than one customer group. Identify the most important groups. Then, for each customer group, construct what is called a demographic profile:

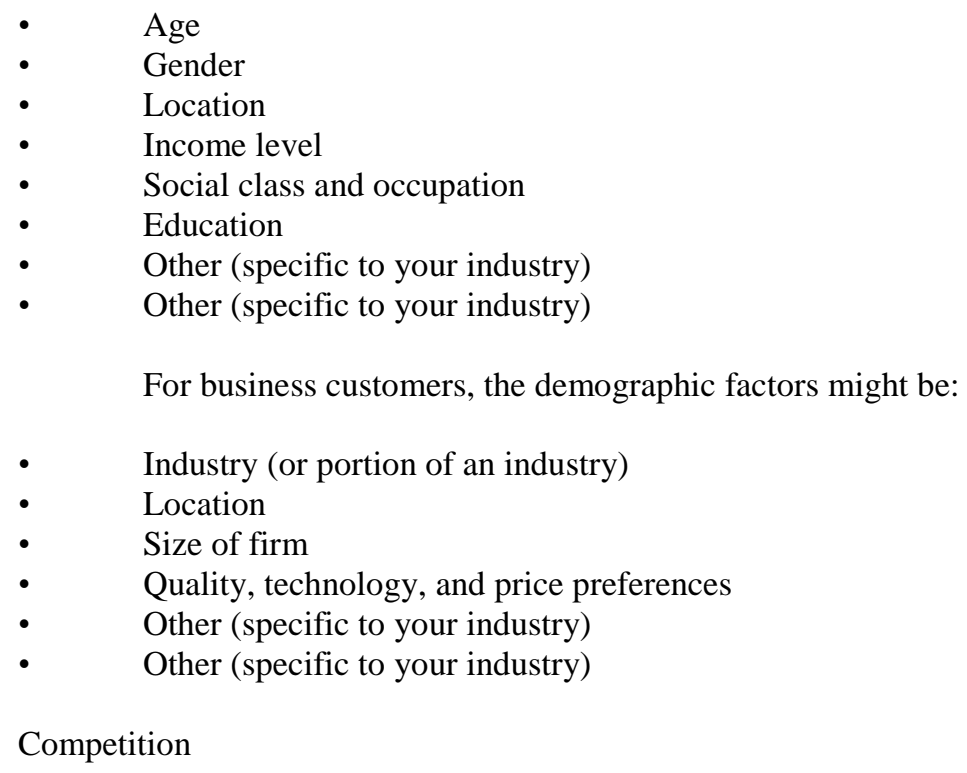

What products and companies will compete with you? 
List your major competitors:

(Names and addresses)

Will they compete with you across the board, or just for certain products, certain customers, or in certain locations?

Will you have important indirect competitors? (For example, video rental stores compete with theaters, although they are different types of businesses.)

How will your products or services compare with the competition?

Compare your company with your two most important competitors. Identify key competitive factors.

Analyze how this will stack up in customers' minds. Then check whether you think this factor will be strength or a weakness for you. Sometimes it is hard to analyze our own weaknesses. Try to be very honest here. Better yet, get some disinterested strangers to assess you. This can be a real eye-opener. And remember that you cannot be all things to all people. In fact, trying to be causes many business failures because efforts become scattered and diluted. You want an honest assessment of your firm's strong and weak points.

Now analyze each major competitor. In a few words, state how you think they compare.

Use an established theory or concept such as SWOT, SWOT/TOWS, or Porter's 5 Forces. Write a short paragraph stating your value proposition and competitive advantages and disadvantages.

Niche

Now that you have systematically analyzed your industry, your product, your customers, and the competition, you should have a clear picture of where your company fits into the world. In one short paragraph, define your niche, your unique corner of the market.

Strategy

Now outline a marketing strategy that is consistent with your niche.

Promotion

How will you get the word out to customers?

Advertising: What media, why, and how often? Why this mix and not some other?

Have you identified low-cost methods to get the most out of your promotional budget?

Will you use methods other than paid advertising, such as trade shows, catalogs, dealer incentives, word of mouth (how will you stimulate it?), and network of friends or professionals? What image do you want to project? How do you want customers to see you? In addition to advertising, what plans do you have for graphic image support? This includes things like logo design, cards and letterhead, brochures, signage, and interior design (if customers come to your place of business). Should you have a system to identify repeat customers and then systematically contact them?

Promotional Budget

How much will you spend on the items listed above? Before startup? (These numbers will go into your startup budget.) Ongoing? (These numbers will go into your operating plan budget.) 
Pricing

Explain your method or methods of setting prices. For most small businesses, having the lowest price is not a good policy. It robs you of needed profit margin; customers may not care as much about price as you think; and large competitors can under price you anyway. Usually you will do better to have average prices and compete on quality and service. Does your pricing strategy fit with what was revealed in your competitive analysis? Compare your prices with those of the competition. Are they higher, lower, the same? Why? How important is price as a competitive factor? Do your intended customers really make their purchase decisions mostly on price? What will be your customer service and credit policies?

Proposed Location

Probably you do not have a precise location picked out yet. This is the time to think about what you want and need in a location. Many startups run successfully from home for a while.

You will describe your physical needs later, in the Operational Plan section. Here, analyze your location criteria as they will affect your customers. Is your location important to your customers? If yes, how? If customers come to your place of business:

Is it convenient? Parking? Interior spaces? Not out of the way? Is it consistent with your image? Is it what customers want and expect? Where is the competition located? Is it better for you to be near them (like car dealers or fast food restaurants) or distant (like convenience food stores)?

Distribution Channels

- How do you sell your products or services?

- Retail

- $\quad$ Direct (mail order, Web, catalog)

- Wholesale

- Your own sales force

- $\quad$ Agents

- Independent representatives

- $\quad$ Bid on contracts

\section{Sales Forecast}

Now that you have described your products, services, customers, markets, and marketing plans in detail, it's time to attach some numbers to your plan. The forecast should be based on your historical sales, the marketing strategies that you have just described, your market research, and industry data, if available.

You may want to do two forecasts: 1) a "best guess", which is what you really expect, and 2) a "worst case" low estimate that you are confident you can reach no matter what happens. Remember to keep notes on your research and your assumptions as you build this sales forecast and all subsequent spreadsheets in the plan. This is critical if you are going to present it to funding sources.

\section{Operational Plan}

Explain the daily operation of the business, its location, equipment, people, processes, and surrounding environment.

Production

How and where are your products or services produced? 
Explain your methods of:

- $\quad$ Production techniques and costs

- Quality control

- $\quad$ Customer service

- Inventory control

- $\quad$ Product development

Location

What qualities do you need in a location? Describe the type of location you'll have.

Physical requirements:

- Amount of space

- $\quad$ Type of building

- $\quad$ Zoning

- $\quad$ Power and other utilities

Access:

Is it important that your location be convenient to transportation or to suppliers?

Do you need easy walk-in access?

What are your requirements for parking and proximity to freeway, airports, railroads, and shipping centers? Include a drawing or layout of your proposed facility if it is important, as it might be for manufacturer.

Most new companies should not sink capital into construction, but if you are planning to build, costs and specifications will be a big part of your plan.

Cost:

Estimate your occupation expenses, including rent, but also including maintenance, utilities, insurance, and initial remodeling costs to make the space suit your needs. These numbers will become part of your financial plan. What will be your business hours?

\section{Legal Environment:}

- $\quad$ Licensing and bonding requirements

- $\quad$ Permits

- Health, workplace, or environmental regulations

- Special regulations covering your industry or profession

- $\quad$ Zoning or building code requirements

- Insurance coverage

- $\quad$ Trademarks, copyrights, or patents (pending, existing, or purchased)

Personnel:

- $\quad$ Number of employees

- Type of labor (skilled, unskilled, and professional)

- Where and how will you find the right employees?

- Quality of existing staff

- $\quad$ Pay structure

(C) 2012 The Clute Institute http://www.cluteinstitute.com/ 
- Training methods and requirements

- Who does which tasks?

- $\quad$ Do you have schedules and written procedures prepared?

- Have you drafted job descriptions for employees? If not, take time to write some. They really help internal communications with employees.

- For certain functions, will you use contract workers in addition to employees?

Inventory

- What kind of inventory will you keep: raw materials, supplies, finished goods?

- $\quad$ Average value in stock (i.e., what is your inventory investment)?

- $\quad$ Rate of turnover and how this compares to the industry averages?

- Seasonal buildups?

- $\quad$ Lead-time for ordering?

Identify key suppliers:

- $\quad$ Names and addresses

- $\quad$ Type and amount of inventory furnished

- $\quad$ Credit and delivery policies

- History and reliability

Should you have more than one supplier for critical items (as a backup)?

Do you expect shortages or short-term delivery problems?

Are supply costs steady or fluctuating? If fluctuating, how would you deal with changing costs?

Credit Policies

- $\quad$ Do you plan to sell on credit?

- Do you really need to sell on credit? Is it customary in your industry and expected by your clientele?

- If yes, what policies will you have about who gets credit and how much?

- How will you check the creditworthiness of new applicants?

- What terms will you offer your customers; that is, how much credit and when is payment due?

- Will you offer prompt payment discounts? (Hint: Do this only if it is usual and customary in your industry.) Do you know what it will cost you to extend credit? Have you built the costs into your prices?

\section{Management and Organization}

Who will manage the business on a day-to-day basis? What experience does that person bring to the business? What special or distinctive competencies? Is there a plan for continuation of the business if this person is lost or incapacitated?

If you'll have more than 10 employees, create an organizational chart showing the management hierarchy and who is responsible for key functions.

Include position descriptions for key employees. If you are seeking loans or investors, include resumes of owners and key employees.

Professional and Advisory Support, list the following:

- $\quad$ Board of directors

- Management advisory board 
- Attorney

- Accountant

- Insurance agent

- Banker

- Consultant or consultants

- $\quad$ Mentors and key advisors

\section{$\underline{\text { Startup Expenses and Capitalization }}$}

You will have many startup expenses before you even begin operating your business. It's important to estimate these expenses accurately and then to plan where you will get sufficient capital. This is a research project, and the more thorough your research efforts, the less chance that you will leave out important expenses or underestimate them.

Even with the best of research, however, opening a new business has a way of costing more than you anticipate. There are two ways to make allowances for surprise expenses. The first is to add a little "padding" to each item in the budget. The problem with that approach, however, is that it destroys the accuracy of your carefully wrought plan. The second approach is to add a separate line item, called contingencies, to account for the unforeseeable. This is the approach we recommend.

Talk to others who have started similar businesses to get a good idea of how much to allow for contingencies. If you cannot get good information, we recommend a rule of thumb that contingencies should equal at least 20 percent of the total of all other start-up expenses.

Explain your research and how you arrived at your forecasts of expenses. Give sources, amounts, and terms of proposed loans. Also explain in detail how much will be contributed by each investor and what percent ownership each will have.

\section{$\underline{\text { Financial Plan }}$}

The financial plan consists of a five year profit and loss projection, a four-year profit and loss projection (optional), a cash-flow projection, a projected balance sheet, and a break-even calculation. Together they constitute a reasonable estimate of your company's financial future. More important, the process of thinking through the financial plan will improve your insight into the inner financial workings of your company. The following is required:

- $\quad$ 12-Month Profit and Loss Projection (not required for the class but needed for other purposes). Many business owners think of the 12-month profit and loss projection as the centerpiece of their plan. This is where you put it all together in numbers and get an idea of what it will take to make a profit and be successful. Your sales projections will come from a sales forecast in which you forecast sales, cost of goods sold, expenses, and profit month-by-month for one year. Profit projections should be accompanied by a narrative explaining the major assumptions used to estimate company income and expenses.

Research Notes: Keep careful notes on your research and assumptions, so that you can explain them later if necessary, and also so that you can go back to your sources when it's time to revise your plan.

- $\quad$ Five-Year Profit Projection

Use the template provided to develop a five year forecast for your business. This forecast must include a balance sheet, an income statement, a statement of cash flow, and you must explain the assumptions and characteristics for your business.

- $\quad$ Projected Cash Flow 
If the profit projection is the heart of your business plan, cash flow is the blood. Businesses fail because they cannot pay their bills. Every part of your business plan is important, but none of it means a thing if you run out of cash.

The point of this worksheet is to plan how much you need before startup, for preliminary expenses, operating expenses, and reserves. You should keep updating it and using it afterward. It will enable you to foresee shortages in time to do something about them-perhaps cut expenses, or perhaps negotiate a loan. But foremost, you shouldn't be taken by surprise. There is no great trick to preparing it: The cash-flow projection is just a forward look at your checking account. For each item, determine when you actually expect to receive cash (for sales) or when you will actually have to write a check (for expense items). You should track essential operating data, which is not necessarily part of cash flow but allows you to track items that have a heavy impact on cash flow, such as sales and inventory purchases. You should also track cash outlays prior to opening in a pre-startup column. You should have already researched those for your startup expenses plan. Your cash flow will show you whether your working capital is adequate. Clearly, if your projected cash balance ever goes negative, you will need more start-up capital. This plan will also predict just when and how much you will need to borrow. Explain your major assumptions; especially those that make the cash flow differ from the Profit and Loss Projection. For example, if you make a sale in month one, when do you actually collect the cash? When you buy inventory or materials, do you pay in advance, upon delivery, or much later? How will this affect cash flow. Are some expenses payable in advance? When? Are there irregular expenses, such as quarterly tax payments, maintenance and repairs, or seasonal inventory buildup that should be budgeted?

Loan payments, equipment purchases, and owner's draws usually do not show on profit and loss statements but definitely do take cash out. Be sure to include them.

And of course, depreciation does not appear in the cash flow at all because you never write a check for it.

- $\quad$ Opening Day Balance Sheet

A balance sheet is one of the fundamental financial reports that any business needs for reporting and financial management. A balance sheet shows what items of value are held by the company (assets), and what its debts are (liabilities). When liabilities are subtracted from assets, the remainder is owners' equity.

Use a startup expenses and capitalization spreadsheet as a guide to preparing a balance sheet as of opening day. Then detail how you calculated the account balances on your opening day balance sheet.

Optional: Some people want to add a projected balance sheet showing the estimated financial position of the company at the end of the first year. This is especially useful when selling your proposal to investors.

- $\quad$ Break-Even Analysis

A break-even analysis predicts the sales volume, at a given price, required to recover total costs. In other words, it's the sales level that is the dividing line between operating at a loss and operating at a profit. Expressed as a formula, break-even is:

Break-Even Sales $\quad=$ Fixed Costs $/(1-$ Variable Costs $)$

(Where fixed costs are expressed in dollars, but variable costs are expressed as a percent of total sales.) Include all assumptions upon which your break-even calculation is based. 